\title{
ACESSO À INFORMAÇÃO NO GOVERNO MUNICIPAL: TRANSPARÊNCIA DAS INFORMAÇÕES DOS MUNICÍPIOS DA REGIÃO METROPOLITANA DE CAMPINAS/SP
}

\author{
Luana Gomes Milanez*, Wagner de Melo Romão.
}

\begin{abstract}
Resumo
Com a Constituição Federal de 1988 nasce a preocupação do governo com o acesso à informação, mas é em 2011 que é criada a Lei de Acesso à Informação que abrange os governos federais, estaduais e municipais. É a partir dessa lei que esse trabalho se dedicou a elaborar indicadores de transparência e buscou avaliar os Portais de Acesso à informação, tanto das Prefeituras Municipais, quanto das Câmaras de Vereadores de cada cidade da Região Metropolitana de Campinas (RMC). Com essa avaliação foi possível criar um Ranking de Transparência da RMC.
\end{abstract}

\section{Palavras-chave:}

Transparência, participação pública, acesso à informação.

\section{Introdução}

Com a redemocratização e a nova Constituição Federal de 1988, há uma nascente preocupação com o direito ao acesso à informação. É a partir dessa ideia que é criada a Lei de Acesso à Informação (2011) ${ }^{1}$, onde se estabelecem critérios de abertura de dados para os governos federais, estaduais e municipais.

Tendo essa lei como parâmetro, este trabalho se dedicou a produzir um ranking de transparência das Prefeituras Municipais e das Câmaras de Vereadores de cada município da região metropolitana de Campinas (RMC), composta por vinte cidades.

A elaboração desse ranking foi feita com o objetivo de produzir uma ferramenta para o uso da ciência política, onde esperamos ser possível perceber o nível da disponibilização de informações aos cidadãos.

\section{Resultados e Discussão}

Com base na Lei de Acesso à Informação (2011) foram elaborados vinte e cinco indicadores de transparência para que se pudesse avaliar os Portais de Acesso à Informação das Prefeituras Municipais e das Câmaras dos Vereadores de cada município da RMC. Cada indicador de transparência foi aprimorado, tendo como inspiração os indicadores utilizados pelo Observatório Cidadão de Piracicaba, que também tem por objetivo fiscalizar os Portais de Acesso à Informação da Prefeitura Municipal e da Câmara dos Vereadores da cidade de Piracicaba.

Os sites da Prefeitura Municipal e da Câmara dos Vereadores geralmente possuíam um link para entrar no Portal de Acesso à Informação. Nele foi feito um levantamento de dados, a partir da verificação se o portal estava de acordo com a LAI (2011), com base nos indicadores de transparência que foram criados.

A partir dos dados levantados foi possível fazer uma pontuação para cada cidade da $\mathrm{RMC}$, obedecendo à seguinte forma de pontuação para cada indicador: 0 Não contém a informação; 1 - Contém poucas informações; 2 - Contém informações quase suficientes e 3 - Contém informações.

Com isso elaboramos o Ranking de Transparência das Prefeituras e Câmaras de Vereadores da RMC (Tabela 1), que se vê na primeira coluna as posições das cidades no ranking e nas colunas três e cinco a pontuação de cada cidade.
Tabela 1. Ranking de Transparência das Prefeituras e Câmaras de Vereadores da RMC

\begin{tabular}{|c|l|l|l|l|}
\hline & Prefeitura Municipal & & $\begin{array}{c}\text { Câmara dos } \\
\text { Vereadores }\end{array}$ & \\
\hline 1 & Indaiatuba & 72 & Cosmópolis & 72 \\
\hline 2 & Cosmópolis & 70 & Indaiatuba & 72 \\
\hline 3 & Morungaba & 68 & Campinas & 71 \\
\hline 4 & Americana & 64 & Jaguariúna & 70 \\
\hline 5 & Artur Nogueira & 63 & Santa B. d'Oeste & 66 \\
\hline 6 & Valinhos & 63 & Americana & 65 \\
\hline 7 & Campinas & 62 & Monte Mor & 63 \\
\hline 8 & Itatiba & 62 & Pedreira & 63 \\
\hline 9 & Nova Odessa & 62 & Santo A. da Posse & 61 \\
\hline 10 & Paulínia & 62 & Engenheiro Coelho & 60 \\
\hline 11 & Pedreira & 61 & Morungaba & 59 \\
\hline 12 & Santo A. da Posse & 60 & Nova Odessa & 58 \\
\hline 13 & Hortolândia & 59 & Vinhedo & 57 \\
\hline 14 & Holambra & 53 & Artur Nogueira & 55 \\
\hline 15 & Vinhedo & 50 & Sumaré & 53 \\
\hline 16 & Engenheiro Coelho & 47 & Paulínia & 50 \\
\hline 17 & Santa B. d'Oeste & 43 & Holambra & 45 \\
\hline 18 & Jaguariúna & 41 & Valinhos & 41 \\
\hline 19 & Sumaré & 37 & Hortolândia & 39 \\
\hline 20 & Monte Mor & 35 & Itatiba & 39 \\
\hline & & & \\
\hline
\end{tabular}

Conclusões

Foi observado que os portais de acesso à informação desses municípios geralmente possuem boas informações e devidamente atualizadas. Contudo, também observamos que alguns portais deixavam a aplicação os indicadores de transparência muito difícil, tendo em vista que estavam extremamente desorganizados. Em relação ao ranking, impressiona os dois primeiros colocados, tanto da Prefeitura Municipal, como da Câmara dos Vereadores serem os mesmos. Mas também apareceram cidades com diferenças muito grandes entre a Prefeitura Municipal e a Câmara dos Vereadores.

\section{Agradecimentos}

Agradeço o meu professor orientador Wagner de Melo Romão, por todo empenho, dedicação e paciência ao me ajudar com essa pesquisa. Também gostaria de agradecer a PIBIC/CNPq e a UNICAMP por possibilitar a execução deste trabalho científico.

${ }^{1}$ BRASIL. Lei ${ }^{\circ} 12.527$, de 18 de novembro de 2011. Regula o acesso a informações previsto no inciso XXXIII do art. $5^{\circ}$, no inciso II do $\S 3^{\circ}$ do art. 37 e no $\S 2^{\circ}$ do art. 216 da Constituição Federal. Brasília, 2011. 